\title{
Occult craniocervical dysraphism and skin markers
}

\author{
George T Vasileiadis
}

Department of Neonatology, BHR University Hospitals NHS Trust, London, UK

\section{Correspondence to} Dr George T Vasileiadis, George.Vasileiadis@ bhrhospitals.nhs.uk

Accepted 26 August 2015
CrossMark

To cite: Vasileiadis GT. BMJ Case Rep Published online: [please include Day Month Year] doi:10.1136/bcr-2015211618

\section{DESCRIPTION}

Neural tissue and skin are of common ectodermal origin and therefore anomalies occurring during early embryogenesis may lead to combined neuroskin malformations. Neural tube closure occurs during primary neurulation starting from the equivalent of the craniocervical junction and proceeding zip-like in both cephalic and caudal directions. ${ }^{1}$ Therefore, any defects of the process may reflect spinal dysraphism with, possibly, combined congenital skin lesions.

Occult spinal dysraphism (not exposed but skincovered neural tissue), in the vast majority of cases, is localised in the lumbosacral area and less commonly in the cervicothoracic area. ${ }^{2}{ }^{3}$ This report describes an atypical case of occult craniocervical dysraphism with combined skin lesions/markers.

Routine postnatal examination of a term newborn girl revealed a salmon patch (vascular malformation of capillaries) on the occipital and upper cervical areas, a subcutaneous soft but fixed mass $(1.3 \times 1.2 \times 1.0 \mathrm{~cm})$ on the midline at the level of the craniocervical junction, and hair tufts above and below the mass along the midline (figure 1). The differential diagnosis of meningocoele/myelocoele, lipoma, dermal cyst, fibroma, or hamartoma was made. Brain and spine MRI revealed a

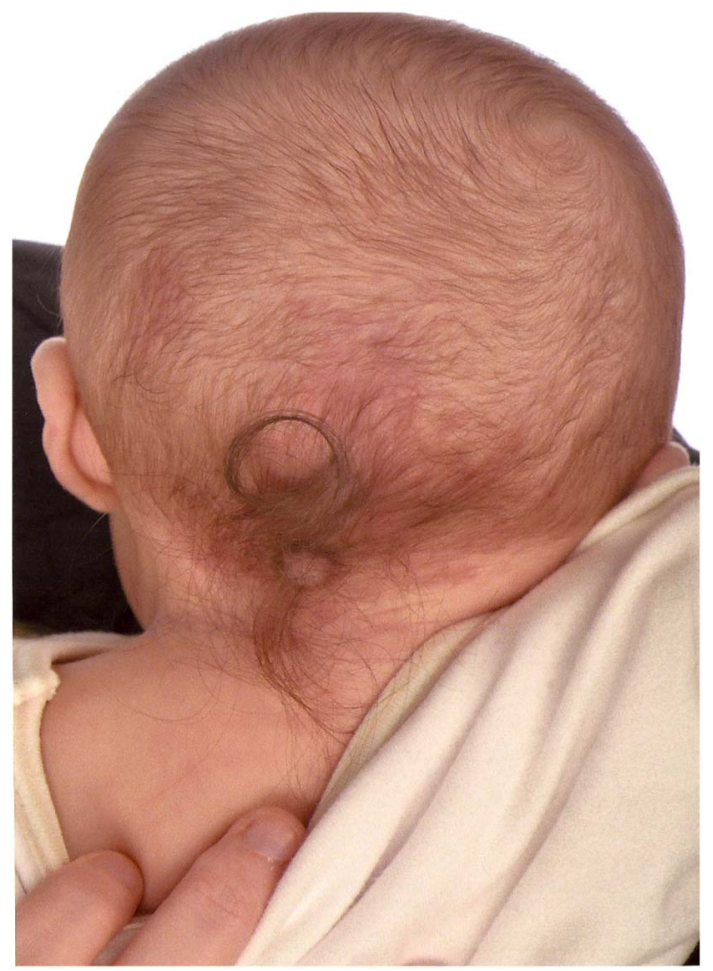

Figure 1 Salmon patch, subcutaneous soft mass and hair tufts along the midline of occipital and craniocervical areas.

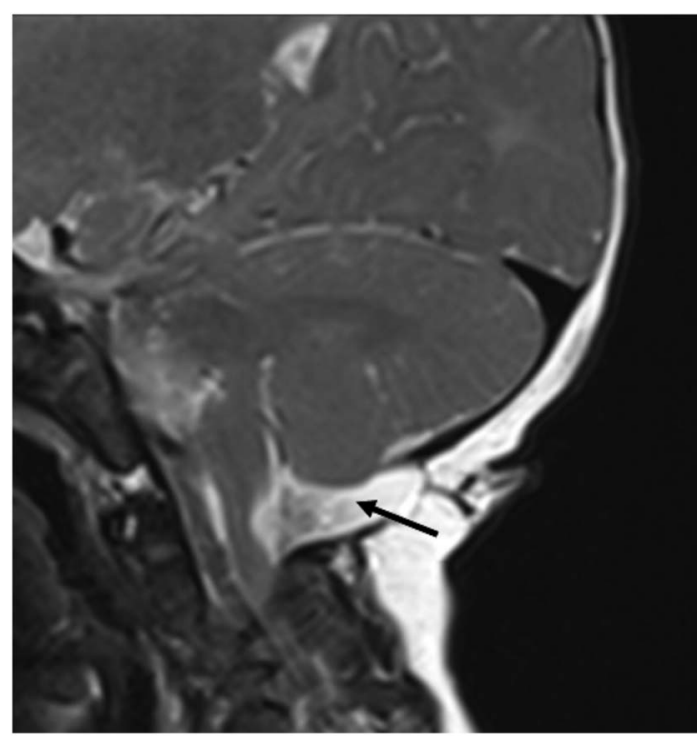

Figure 2 Fluid density tract (T2 TSE sequence, sagittal view, arrow) protruding through the bony defect.

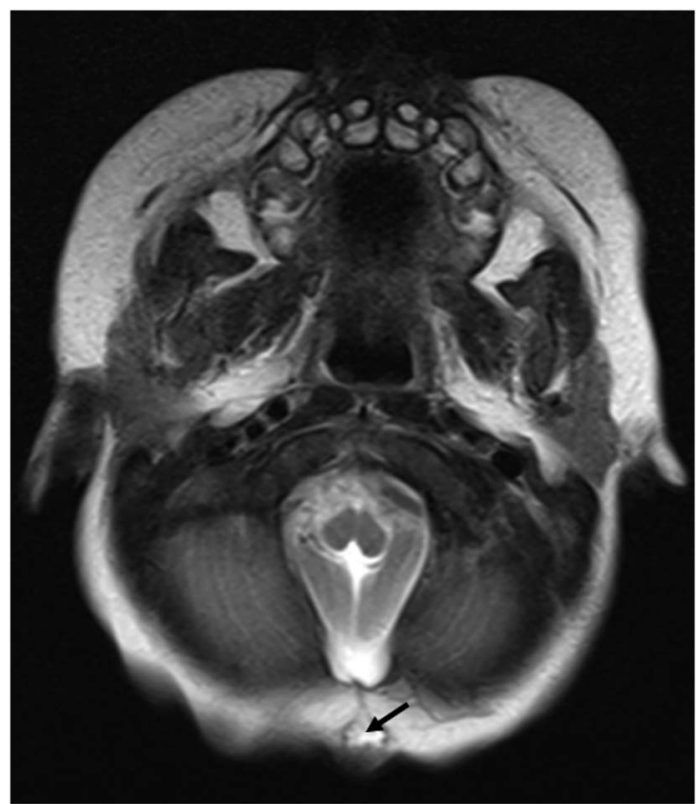

Figure 3 Subcutaneous cyst/occult occipital meningocoele (T2 TSE sequence, axial view, arrow).

complex anomaly of the craniocervical junction with a fluid density tract (figure 2 ) extending from the cisterna magna, and a cerebrospinal fluid space, through a bony defect, to a small subcutaneous cyst (figure 3), providing evidence of an occult occipital meningocoele. There was no herniation of the cerebellum or intracranial contents, and no abnormalities of the lower spine. 


\section{Learning points}

- Craniocervical dysraphism represents an anomaly with its origin in early embryogenesis (week 3 ).

- Neural tissue and skin are of common ectodermal origin and may therefore present combined neuro-skin malformations.

- Occult spinal dysraphism with skin markers may be atypically located in the craniocervical area.
Competing interests None declared.

Patient consent Obtained.

Provenance and peer review Not commissioned; externally peer reviewed.

\section{REFERENCES}

1 Lien RJ, Naidich TP, Delman BN. Embryogenesis of the peripheral nervous system. Neuroimaging Clin N Am 2004;14:1-42.

2 Guggisberg D, Hadj-Rabia S, Viney C, et al. Skin markers of occult spinal dysraphism in children: a review of 54 cases. Arch Dermatol 2004;140:1109-15.

3 Rossi A, Cama A, Piatelli G, et al. Spinal dysraphism: MR imaging rationale J Neuroradiol 2004;31:3-24.

Copyright 2015 BMJ Publishing Group. All rights reserved. For permission to reuse any of this content visit http://group.bmj.com/group/rights-licensing/permissions.

BMJ Case Report Fellows may re-use this article for personal use and teaching without any further permission.

Become a Fellow of BMJ Case Reports today and you can:

- Submit as many cases as you like

- Enjoy fast sympathetic peer review and rapid publication of accepted articles

- Access all the published articles

- Re-use any of the published material for personal use and teaching without further permission

For information on Institutional Fellowships contact consortiasales@bmjgroup.com

Visit casereports.bmj.com for more articles like this and to become a Fellow 